\title{
EM BUSCA DA SOCIOLOGIA NÃO PAROQUIAL*
}

\section{Renan Springer de Freitas}

O título deste artigo encerra a premissa de que a Sociologia, como de resto qualquer ciência, não deve ter um caráter paroquial. Essa premissa, devo logo dizer, está muito longe de ser trivial. Nos últimos 20 ou 30 anos, parte considerável da sociologia do conhecimento tem se movido exatamente em torno da tese oposta, qual seja, a de que a ciência é sobretudo a prática organizada de um grupo e, portanto, é uma forma tão paroquial de conhecimento quanto qualquer outra. Neste artigo eu discuto a trajetória dessa visão paroquial da ciência, suas deficiências e, principalmente, os ganhos que poderiam ser obtidos com a sua erradicação.

Vou iniciar a discussão sugerindo uma distinção entre ironizar e operar ironicamente. 1 Ironizar envolve ter alguma vítima como alvo. Se o alvo da ironia é uma determinada afirmação, a vitimização se faz contrastando esta afirmação com alguma afirmação alternativa, de modo a sugerir que esta última encerra alguma verdade que a primeira mantém encoberta. Na medida em que supõe uma vítima, o ato de ironizar requer algum grau de solidariedade entre o irônico e sua audiência. Se o irônico não puder contar com esta solidariedade, o efeito irônico não se obtém. A ironia só é, então, ironia no interior do grupo. Fora do grupo, ela não é nada. Retornarei a esse ponto oportunamente. Operar ironicamente, em radical contraste, não envolve nada do que acabo de descrever. Não envolve vitimização, nem contraste, nem muito menos qualquer forma de solidariedade. Envolve, sim, tomar distância do objeto sob investigação para examinar sua trajetória ao longo do tempo. Assim, se para ironizar uma afirmação tal como, por exemplo, "o homem descende do macaco", é necessário contrastar esta afirmação com alguma afirmação alternativa visando, com este contraste, revelar alguma verdade que escapa à citada afirmação, para operar ironicamente em relação a esta mesma afirmação é necessário afastar-se dela para examinar a sua trajetória ao longo do tempo e avaliar se ela resultou ou não em alguma coisa. Trata-se, nesse caso, de examinar como esta afirmação se relaciona com outras afirmações, não importa de que época ou lugar, e, a partir daí, perguntar se tal afirmação se torna mais clara ou mais fecunda se relacionada com estas outras afirmações, se ela corrige alguma afirmação anterior e/ou é 
de alguma forma corrigida por alguma afirmação posterior e, finalmente, se esta afirmação veio, com a passagem do tempo, a sugerir algum problema para ser resolvido ou se, ao contrário, acabou por se degenerar.

Em um trabalho anterior (Springer de Freitas, 1993), argumentei que a ironia vitimizadora que descrevi acima é o traço fundamental da sociologia do conhecimento que se desenvolveu nos últimos 20 ou 30 anos. Nesse mesmo artigo apresentei o trabalho de Bruno Latour como sendo uma genuína alternativa não irônica a esta sociologia do conhecimento. Naquela época, Latour não havia ainda publicado o seu aclamado We have never been modern. No entanto, o fundamental deste livro já estava presente nos artigos que tomei como referência (Latour, 1983, 1990 e 1991). Na época, eu vi nesses artigos um bom exemplo de como operar ironicamente sem incorrer na ironia paroquial da sociologia do conhecimento de matriz wittgensteiniana. Hoje, entretanto, mudei de opinião. O livroObjective knowledge, de Karl Popper (1992 [1972]), cuja presença se faz claramente notar em cada página deste artigo, levou-me à opinião de que a sociologia de Latour não representa nenhuma contribuição significativa para o entendimento de qualquer coisa que diga respeito ao conhecimento. Para entender como o conhecimento é gerado e, muito mais importante do que isto, retido ao longo do tempo, é necessário saber como teorias podem ser formuladas e corrigidas. Nesse sentido, dizer alguma coisa relevante sobre o conhecimento envolve sobretudo oferecer resposta para duas perguntas: como teorias se sucedem umas às outras com a passagem do tempo, e o que se ganha (ou, eventualmente, se perde) com tais sucessões. Como, por exemplo, a teoria da seleção clonal veio a suceder as teorias instrucionistas em imunologia e o que se ganhou (ou, eventualmente, se perdeu) com tal sucessão?

Receio que Latour nada tem a dizer sobre questões desta natureza; pior do que isto, sua perspectiva impede que tais questões sejam sequer levantadas. Isto não seria um grande problema se sua perspectiva levantasse questões tão ou mais importantes do que essas. Receio, entretanto, não ser este o caso. E há uma boa razão para isto: Latour concentra-se em algo cujo exame não é tão importante quanto ele supõe. Refiro-me às controvérsias científicas $\underline{2}$ e às estratégias adotadas pelos cientistas para obter $\mathrm{O}$ assentimento de seus pares (ou da sociedade de um modo geral). Assim, em seu artigo de 1983, Latour descreve as estratégias adotadas por Pasteur para tornar seu laboratório imprescindível para a sociedade francesa. Tal descrição, por mais interessante que possa parecer, é irrelevante para entender a trajetória posterior da teoria da fermentação de Pasteur. Nos artigos de 1990 e de 1991, Latour examina a controvérsia entre Boyle e Hobbes a respeito da existência do vácuo. Ele procura mostrar que esta controvérsia envolveu outra muito mais importante, a respeito dos fundamentos do conhecimento e da ordem social. $\underline{3}$ Hobbes pensava que a tese da existência do vácuo poderia conduzir a uma convulsão social. Boyle teve de argumentar que isto não era verdade. Que importância tem tudo isto, é uma pergunta para a qual não tenho resposta. O fato de Hobbes ter um dia contestado a teoria do vácuo nada nos diz sobre o que, do ponto de vista do conhecimento, realmente importa, a saber, a trajetória desta teoria nos seus trezentos anos de existência. A bem da verdade, penso que não apenas Latour, mas a esmagadora maioria dos sociólogos (ou antropólogos) da ciência, dão uma imerecida importância ao exame do que eles mesmos chamam de "science in the making". Eles têm buscado extrair de tal exame muito mais do que ele tem a oferecer. Retornarei a este ponto no final deste artigo. Por ora, quero dizer que com o presente artigo pretendo corrigir meu trabalho de 1993, no qual, em razão de ter me deixado seduzir pela retórica de Latour, perdi uma boa oportunidade de discutir as características da Sociologia não paroquial.

Antes de ir adiante, dois curtos esclarecimentos. Primeiro: a expressão "Sociologia não paroquial" é, num certo sentido, imprópria, porque dá a entender que pode haver uma genuína Sociologia paroquial. Segundo: meu empenho em corrigir meu erro não teria o menor interesse se a ironia paroquial de Latour, e da sociologia do conhecimento de matriz wittgensteiniana de um modo geral, não fosse um traço tão característico do pensamento sociológico contemporâneo. 


\section{A trajetória da visão paroquial do conhecimento}

A visão paroquial do conhecimento remonta à tese durkheimiana de que todo conhecimento se origina do processo por meio do qual pessoas determinadas vêm a partilhar certas crenças em circunstâncias sociais determinadas. Se conhecer é partilhar crenças, e se partilhar crenças implica pertencer a um grupo, então fora do grupo (ou de relações sociais determinadas) não há conhecimento. Esta forma de paroquialismo foi revivida nos anos 50, com a tese wittgensteiniana de que não há conhecimento fora das regras que regem o uso de palavras determinadas em comunidades determinadas; ganhou impulso nos anos 60, com a tese kuhniana de que o conhecimento científico é a propriedade comum de um grupo ou então não é nada, e atingiu seu apogeu nos anos 70, com o aparecimento de um programa de pesquisa que veio a ser conhecido como "construtivismo social", o qual, ancorando-se em Kuhn e em Wittgenstein, empenha-se em mostrar que qualquer forma de conhecimento, inclusive o científico, é contingente a jogos de interesses e a acordos localizados. ${ }^{4}$ Seu foco de atenção são os modos pelos quais os cientistas chegam a um acordo sobre o que considerar um "fato científico", ou uma "boa" teoria, ou uma "evidência", ou uma "corroboração empírica", ou um "experimento crucial", ou um experimento "bemsucedido", ou uma "replicação de um experimento", ou um argumento "válido", ou uma "refutação" de uma teoria, ou um "erro" etc.

No que me concerne, não vejo qualquer problema em pretender investigar como os cientistas chegam a algum acordo sobre o que quer que seja. Não obstante, penso que não se deve atribuir ao que se descobre uma importância maior do que a merecida. Os construtivistas descobriram que, na comunidade científica, o consenso não brota espontaneamente de experimentos cruciais. Eles descobriram que resultados experimentais podem ser interpretados de formas diferentes em circunstâncias diferentes e, por esta razão, não constituem necessariamente um tribunal de última instância ao qual os cientistas podem apelar para resolver de uma vez por todas qualquer disputa. Quanto a isto, eles estão obviamente certos. Penso, entretanto, que eles pretenderam extrair desta trivialidade muito mais do que ela tem a oferecer e, ao fazê-lo, eles conduziram a visão paroquial do conhecimento inaugurada por Durkheim, e revigorada por Kuhn e Wittgenstein, ao seu apogeu. Os construtivistas vislumbraram nesta "descoberta" de que um mesmo resultado experimental pode ser aduzido em favor de teorias diferentes (ou mesmo opostas) uma solução para um problema de ordem metodológica — o da adequação entre dados e teoria, ou entre um enunciado e a realidade que este enunciado descreve. No que se segue pretendo mostrar o caráter paroquial desta solução para, na seção final, sair em busca da (perdida) ironia sociológica não paroquial.

\section{O apogeu e a inviabilidade da visão paroquial da ciência}

A bem da verdade, o problema da adequação entre dados e teoria (o qual pode ser expresso nos termos: o que justifica a afirmação de que um determinado dado corrobora uma determinada teoria?), ou entre um enunciado e a realidade que ele descreve (o qual se traduz em questões do tipo: o que justifica afirmar que uma representação gráfica da configuração atômica de uma liga metálica corresponde mesmo a esta configuração atômica?), não requer a intervenção de qualquer sociologia do conhecimento muito menos a solução paroquial dos construtivistas, a ser brevemente descrita. Bartley (1987), um importante e negligenciado discípulo de Popper, apresenta uma solução não paroquial que me parece bastante satisfatória. $O$ conhecimento, argumenta Bartley, é sempre indireto e vicarial. A visão, por exemplo, é um substituto (ou vicário) para a locomoção. Quando não se pode contar com este substituto, como ocorre entre os morcegos, outro substituto se faz necessário - no caso, as ondas sonoras que os morcegos emitem, as quais, diga-se de passagem, são um excelente vicário. E, quando uma espécie não tem 
qualquer vicário para a locomoção, como é o caso do paramécio, seus indivíduos estão condenados a colidir permanentemente com os objetos físicos que os rodeiam. O conhecimento da configuração atômica de uma liga metálica é tão indireto quanto o conhecimento de que há um obstáculo físico diante de nós. Ele supõe, portanto, a existência de vicários. Se o único vicário disponível fosse uma representação gráfica (a qual poderia ser obtida, por exemplo, via espectrofotometria), então, com ou sem a ajuda da sociologia do conhecimento, estaríamos perdidos — como também estaríamos perdidos (com ou sem a ajuda da sociologia do conhecimento) se a visão fosse o único vicário com o qual pudéssemos contar para saber o que há diante de nós. Mas, como há mais de um vicário para a configuração atômica de uma liga metálica, podemos nos perguntar se a representação gráfica e os demais vicários convergem em uma mesma direção. Se a resposta for afirmativa, então é razoável postular a hipótese de que há uma adequação entre a referida configuração atômica e a referida representação gráfica. Se, ao contrário, esta representação gráfica não coere com os outros vicários, então é provável que haja alguma coisa errada em relação a ela - embora não seja inteiramente descartável a hipótese de o erro estar nos outros vicários.

Não sei se esta solução 5 é a melhor possível mas, certamente, é bem melhor do que a solução que os construtivistas escolheram como sparring. Tendo simplesmente ignorado esta solução popperiana, eles passaram a golpear um defunto, a saber, a tese, que Popper enterrou há mais de 60 anos, de que existe uma realidade imediatamente disponível para a observação e passível de ser reproduzida tal como é por uma linguagem protocolar. Woolgar (1983) se refere a este defunto como a "posição reflexiva" e observa, com razão, que ele é osparring de parte considerável dos cientistas sociais. $\underline{6}$

Este defunto pode ser golpeado de várias maneiras. Rorty, como indiquei na nota 6 , o golpeou com o argumento de que não há como justificar uma crença sem apelar para os padrões aceitos por uma comunidade. Os construtivistas, por sua vez, o golpearam com base em sua já mencionada descoberta de que um mesmo dado ou resultado experimental pode ser aduzido em favor de teorias diferentes ou mesmo opostas. Se há esta possibilidade, dizem os construtivistas, é porque a interpretação dos dados (ou dos resultados experimentais) é necessariamente mediada por circunstâncias sociais determinadas e, em decorrência, um entendimento adequado da geração de conhecimento não pode prescindir do exame dessas circunstâncias sociais mediadoras. Posto de outra forma, a sociologia do conhecimento de matriz wittgensteiniana quer tirar o máximo proveito do fato de que não existe uma correspondência de um por um entre teorias e evidências. 7 Se uma mesma evidência pode ser aduzida em favor de duas teorias opostas, "a" e "b", isto significa, por tudo o que sei, que esta evidência é inútil, havendo, portanto, a necessidade de alguma outra evidência que possa corroborar apenas "a", ou apenas "b". Os construtivistas, entretanto, tomam o fato de que uma mesma evidência pode ser aduzida tanto em favor de "a" quanto em favor de "b" como a prova cabal de que nem "a" nem "b" podem espelhar alguma realidade que seja independente dos procedimentos metodológicos sancionados pelas comunidades nas quais "a" e "b" foram produzidas. Nos marcos desse raciocínio, não pode haver outra alternativa para a tese defunta de que há um fenômeno imediatamente observável chamado configuração atômica, por um lado, e uma representação gráfica que nos dá acesso direto e inequívoco a este fenômeno por outro, a não ser a tese paroquial de que tanto a configuração atômica, quanto a representação gráfica, quanto a adequação entre ambas, são o resultado de acordos estabelecidos entre os cientistas em circunstâncias sociais particulares. De acordo com esta tese, se não há acesso direto à referida configuração atômica, então este acesso só pode ser obtido através da mediação de tais circunstâncias sociais. Fora dessas circunstâncias mediadoras não há nem configuração atômica, nem representação gráfica, nem qualquer relação entre ambas. Avaliar a adequação entre uma configuração atômica e uma representação gráfica torna-se, então, uma questão de entender as circunstâncias sociais que viabilizam, em momentos determinados, a afirmação de que há tal adequação, isto é, torna-se uma questão de entender as 
circunstâncias que viabilizam a obtenção de um acordo sobre a existência de tal adequação. Se não há tal acordo, também não há tal adequação.

Isto remete diretamente à minha afirmação anterior de que, ao conferir à tese (trivialmente correta) do caráter não espontâneo do consenso uma importância maior do que a merecida, isto é, ao pretender extrair dessa tese uma solução para o problema da adequação entre um enunciado e a realidade que este enunciado representa, os construtivistas acabaram por conduzir a visão paroquial da ciência ao seu apogeu. Eles o fizeram ao derivar da tese de que o consenso sobre a configuração atômica de uma liga metálica não brota espontaneamente de uma representação gráfica, a tese de que esta representação gráfica, por si mesma, não encerra nenhuma informação sobre a referida configuração metálica - a tese de que esta representação gráfica nada significa sem o aval de uma comunidade. Dito de outra forma, o paroquialismo foi elevado ao seu apogeu ao se extrair da tese de que o consenso sobre a adequação de um enunciado não é espontâneo, a tese de que são as circunstâncias sociais envolvidas na obtenção de tal consenso que fazem de um enunciado o que ele é. Desse ponto de vista, o que há de importante para saber em relação a um determinado enunciado são as circunstâncias sociais que permitem a uma comunidade determinada chegar a algum consenso sobre a sua adequação.

É para ter acesso a tais circunstâncias sociais que os construtivistas se debruçam sobre seu objeto de estudo favorito: as controvérsias científicas. Assim, Mackenzie (1978) examina os bastidores da controvérsia entre Yule e Pearson a respeito da adequação de suas respectivas medidas de associação estatística, os bem conhecidos Q de Yule e $\mathrm{C}$ de Pearson. Para mostrar o que há por trás dos argumentos apresentados por Yule e Pearson (Pearson argumentava, contra Yule, que o coeficiente Q tem pouco poder preditivo), Mackenzie menciona que enquanto Pearson fazia parte de um pequeno grupo de estatísticos que partilhavam preocupações eugênicas, Yule não tinha afiliação definida e tomava a predição estatística como um fim em si mesma. Além disto, enquanto Pearson pertencia a uma classe profissional em ascensão, que buscava se afirmar como superior em razão das habilidades intelectuais de seus membros, Yule pertencia a uma elite conservadora decadente, que repelia o que quer que soasse como eugenia. Mackenzie sugere que tudo isto interveio no curso da controvérsia e que, portanto, nem mesmo a teoria estatística se acha a salvo da influência de fatores extracognitivos.

Desnecessário dizer que Mackenzie é silencioso sobre o que de fato importa, a saber, o impacto desses fatores extracognitivos sobre a trajetória posterior das referidas medidas de associação estatística. Não obstante, concedamos a Mackenzie que as informações acima (a de que Yule pertencia a uma elite conservadora decadente, por exemplo) são mesmo muito importantes. Concedamos que não podemos compreender a evolução da estatística a menos que tomemos tais informações em consideração. $\mathrm{O}$ que resulta daí? Isto: nós, cientistas sociais, estamos todos convidados a ver, nas afirmações dos cientistas, alguma coisa diferente do que os cientistas afirmam. Se, por exemplo, Pearson afirma que o coeficiente $Q$ tem pouco poder preditivo, estamos todos convidados a ver nesta afirmação uma preocupação com a eugenia. Estamos, portanto, convidados a ironizar tal afirmação, isto é, a contrastá-la com alguma afirmação alternativa e a ver, em tal afirmação alternativa, a verdade que a afirmação original encobre. Posto que os construtivistas operam através desse tipo de convite, a ironia é seu método de demonstrar o caráter "contingente" e "socialmente construído" do conhecimento.

Entretanto, e isto é crucial, esta ironia não é viável, porque, conforme se verá, ela é incapaz de se sustentar sem a ajuda da banida posição reflexiva. A principal arma que esta ironia tem contra suas vítimas (no caso, os argumentos levantados por cientistas nos cursos de controvérsias) é o contraste entre documentos — isto é, publicações científicas, declarações informais dos cientistas e descrições de procedimentos adotados por cientistas. Assim, o que os cientistas escrevem é contrastado com o que os cientistas dizem, e somos convidados a ver, no que os cientistas dizem, a realidade que escapa ao que os cientistas escrevem. Dados estatísticos são contrastados com uma descrição das 
atividades envolvidas na produção destes dados, e somos convidados a ver, em tal descrição, a realidade que escapa aos dados estatísticos. Assim, em seus estudos sobre o suicídio, tanto Douglas (1967) quanto Atkinson (1978) nos convidam a ver, em suas descrições das atividades dos legistas, a realidade que escapa aos dados estatísticos. A tese central de ambos é a de que os dados estatísticos sobre o suicídio refletem, mais do que taxas reais de suicídio, os pressupostos que orientam o trabalho dos legistas. ${ }^{8} \mathrm{Da}$ mesma forma, Cicourel (1968) contrasta estatísticas policiais com a sua própria descrição das atividades nas quais os policiais se engajam para produzir estas estatísticas e conclui que tais estatísticas refletem, mais do que os índices reais de criminalidade, os preconceitos dos policiais.

Como a ironia construtivista pode estabelecer todos estes contrastes sem se ancorar na premissa, própria da banida "posição reflexiva", de que há uma realidade imediatamente disponível para as nossas descrições? A resposta, muito simples, é a de que ela não pode. A coluna vertebral desta ironia é o pressuposto de que há uma descontinuidade entre documentos. Os construtivistas supõem, por exemplo, que declarações informais dos cientistas (nas quais, presumivelmente, as hesitações mostram-se mais visíveis) e publicações científicas constituem descrições alternativas e hierarquizáveis da realidade da investigação científica. Eles supõem, por exemplo, que as declarações que eles extraem dos cientistas ao entrevistá-los revelam a verdade que as publicações científicas encobrem. Mas nenhum argumento é apresentado em favor desta suposição, porque apresentar tal argumento requereria ancorar-se na rejeitada "posição reflexiva". Requereria, no fim das contas, aceitar que o que os cientistas dizem refletem, de maneira inequívoca e imediata, a "realidade" da investigação científica que os outros documentos encobrem. Daí que a ironia dos construtivistas não tem força para fazer da solução construtivista (para o problema da adequação entre um enunciado e a realidade que ele descreve) uma boa alternativa para a "posição reflexiva".2 O caráter paroquial desta ironia acaba por torná-la dependente do defunto que ela escolheu para golpear.
Mas, o que justifica considerar a ironia construtivista uma ironia paroquial?

\section{A Sociologia não paroquial}

Talvez uma boa maneira de responder esta pergunta fosse descrever como seria uma ironia não paroquial. Em termos genéricos, ironia é a figura de linguagem em que se diz alguma coisa pretendendo-se dizer o oposto. A forma paroquial de fazer ironia é, como se viu, solicitar a solidariedade da audiência convidando-a a ver, no que os outros dizem, algo diferente do que foi dito - grifei a palavra "outros" para enfatizar que esta ironia requer uma clara separação entre "nós" (o irônico e sua audiência) e os "outros" (o alvo da ironia). Mas o efeito irônico pode ser obtido de forma não paroquial. Segundo Kierkegaard (1965), um traço essencial da ironia é que o seu reconhecimento é dinâmico e inconclusivo: a força da ironia consiste em mover o leitor de uma posição em que ele não reconhece a ironia para uma posição em que ele vê sua possibilidade. A ironia não pode então supor uma relação estável entre o irônico e sua audiência; ao contrário, sua força depende da fragilidade desta relação — sua força, eu diria, depende da sua capacidade de ignorar qualquer fronteira entre "nós" e "os outros". Assim, o irônico deve sempre contar com a possibilidade de se tornar a vítima de sua própria ironia, ou de ver sua ironia tomada literalmente, ou ainda descartada como uma tolice. A arte da ironia consiste não só em encorajar a audiência a experimentar as implicações de cada uma destas possibilidades, como também em desencorajar esta mesma audiência a sentir-se plenamente confortável quando chega a alguma conclusão.

É ocioso dizer que a ironia dos construtivistas é estranha a tudo isto. Aqui, não há qualquer risco ou movimento envolvido: desde que se faça parte do círculo de convívio, a ironia pode ser confortavelmente reconhecida. A relação entre o irônico e a audiência é totalmente estável. Nesse sentido, a ironia dos construtivistas se compara a uma ironia que consista em vitimizar uma pessoa feia 
estabelecendo um contraste entre os traços desta pessoa e os traços de uma pessoa bonita. O contraste pode até ser instrutivo, mas seu caráter irônico não escapa a quem quer que conheça as pessoas contrastadas. Ninguém é convidado a tomar o contraste literalmente. Nem como descabido. Além disto, a ironia não se estende a outras instâncias: os outros feios (ou os outros bonitos) não são atingidos.

Tudo isto se inverte quando se toma distância dos fenômenos sob investigação, isto é, quando se relaciona estes fenômenos com quaisquer outros fenômenos e se formula qualquer hipótese contra-intuitiva a respeito deles. Para não ir muito longe, tomemos a conhecida tese de Durkheim de que um sério infortúnio não é, em si, uma razão mais forte para o suicídio do que uma ofensa insignificante. Ou sua tese de que a baixa predisposição dos católicos para o suicídio nada tem a ver com a veemência com que o catolicismo condena esse ato. Nenhuma destas teses envolve a ironia paroquial dos construtivistas. Nenhuma destas teses requer alguma medida de solidariedade ou de competência da audiência para se fazer eficaz. $\frac{10}{}$ Nenhuma delas opera apelando para um senso de comunidade — isto é, convidando os colegas a ver alguma coisa que tenha escapado aos não colegas (mesmo porque estas teses dissolvem qualquer fronteira entre "colegas" e "não colegas").11 Ao contrário, a exemplo do ovo, que endurece quando é cozido (ao invés de se desmanchar), estas teses dependem da permanente intransigência da audiência para não se degenerar. Sua sobrevivência depende de sua capacidade de mobilizar a audiência no sentido de explorar suas implicações e, ao mesmo tempo, de desencorajar esta mesma audiência a sentir-se segura quando chega a alguma conclusão.

Isto conduz diretamente ao ponto deste artigo: sempre que estivermos diante de uma afirmação que satisfaça tais requisitos, isto é, que seja capaz de prosperar sem precisar de demarcar fronteiras entre os que fazem parte e os que não fazem parte do grupo (ou, o que dá no mesmo, sem precisar de contar com o assentimento de uma comunidade), estaremos diante de uma genuína ironia sociológica não paroquial. Este ponto, que hoje me parece trivial, escapou-me em meu citado artigo de 1993, a ponto de eu chegar a sugerir que a obra de Bruno Latour fosse um bom exemplo de ironia sociológica. Sustentei que sua sociologia do conhecimento discutia a ciência de Boyle e de Pasteur de forma não paroquial. Hoje percebo que estava muito enganado. Sou grato a Simon Schwartzman por ter me indicado uma maneira bastante econômica de mostrar meu equívoco ao resumir tão bem, em seu instigante livro $A$ redescoberta da cultura, o crucial do pensamento de Latour. No capítulo intitulado "O lugar das ciências sociais" Schwartzman afirma:

[...] o conhecimento científico se desenvolve, na descrição de Bruno Latour, pela progressiva construção de "fatos científicos" que são como caixas-pretas cuja verdade ou adequação é dada como certa para os que a utilizam como ponto de partida para outros estudos, mas cuja natureza problemática pode sempre ser ressaltada quando examinadas em suas origens [...] O ponto central de Latour é que o que dá — ou não — consistência e validade a essas caixaspretas não são tanto suas qualidades intrínsecas iniciais, mas seu uso progressivo, mediante o tempo e o espaço, por um número cada vez maior de pessoas. (Schwartzman, 1997, pp. 30-31) 12

Para Latour, todo conhecimento emana da construção e do uso de "caixas-pretas". Latour ironiza a ciência ao propor que para saber qualquer coisa importante sobre ela é necessário saber como os cientistas lutam para construir e usar as "caixas-pretas" que lhes convêm e destruir as "caixas-pretas" que não lhes convêm. De acordo com esta proposta, só é possível entender as ciências de Pasteur e de Boyle se não se perder de vista que ambos foram, antes de qualquer coisa, dois grandes construtores de "caixaspretas". Não duvido que Pasteur e Boyle tenham sido dois mestres na arte de convencer e de mobilizar interesses dos outros em favor de seus próprios interesses. Mas, na minha opinião, esta é uma verdade irrelevante.

A bem da verdade, para além da ironia embutida nesta metáfora da caixa-preta, não entendo a que essa metáfora vem. Se bem entendo Latour, construir uma "caixa-preta" é encadear elementos de forma tal que atacar um elemento implicaria atacar os demais. Vou recorrer a um exemplo de "caixa-preta" oferecido por Steven Shapin (1995, p. 308) para esclarecer esse ponto. Considere-se o conhecimento físico que um termômetro encerra - o conhecimento, por exemplo, de que o mercúrio se expande com o calor. 
Contestar esse conhecimento, diz Shapin, implicaria brigar em muitas frentes, contra muitas atividades institucionalizadas que dependem da sua total aceitação. Desse ponto de vista, um termômetro comprado na farmácia é uma "caixa-preta" ou, para ser mais preciso, faz parte de uma "caixa-preta" porque envolve o encadeamento de vários elementos (a referida teoria de que o mercúrio se expande com o calor, a prática institucionalizada de tomar a temperatura e recorrer por conta própria a um medicamento em caso de febre, a prática institucionalizada de recorrer a um médico no caso de persistência da febre, a tecnologia envolvida na produção de mercúrio apropriado para termômetros, a reputação e os interesses das indústrias que os produzem etc.), $\underline{13}$ os quais, exatamente por se acharem encadeados, se reforçam mutuamente. Uma vez ocorrido tal encadeamento, o ataque a um elemento qualquer (à referida teoria de que o mercúrio se expande com o calor, por exemplo) envolveria um ataque a todos os outros, o que vale dizer que este elemento, em razão de estar encadeado aos demais, torna-se muito menos vulnerável a ataques. 14

Não vejo problema em concordar com a idéia de que contestar a tese de que o mercúrio se expande com o calor envolveria atravessar o caminho de alguns interesses e de algumas "atividades institucionalizadas". Também não vejo problema em concordar com a tese de que os elementos mencionados acima não precisam estar necessariamente encadeados — ou podem se encadear de maneiras alternativas. Mas, se o tema em questão é o conhecimento, tenho dificuldade em perceber aonde estas verdades podem nos levar.

Para tornar mais claro meu argumento de que a metáfora da caixa-preta, se aplicada ao conbecimento cientifico, não leva a muito longe, vou tomar outro exemplo de "caixa-preta", agora do próprio Latour, e tentar mostrar que podemos fazer melhor proveito desse exemplo mantendo-o afastado da referida metáfora. Trata-se do modelo da estrutura molecular do DNA, conhecido como a teoria da dupla hélice - a qual, em 1955, levou os cientistas Watson e Crick ao Prêmio Nobel. 15 Posto o exemplo, cabe perguntar: o que se ganha considerando a referida teoria uma "caixa- preta"? Em outras palavras: que perguntas somos levados a fazer (e que resposta somos levados a dar) se aceitarmos o convite de Latour para considerar a teoria da dupla hélice uma "caixa- preta"? Se bem entendo o argumento de Latour, a pergunta crucial seria: de onde vem a autoridade desta teoria — ou seja, em que circunstâncias sua aceitação, por um público determinado, se torna mais ou menos imperativa? E a resposta seria: depende dos elementos aos quais ela se encontra encadeada em situações determinadas. Esta teoria estará tanto mais invulnerável a ataques quanto mais um ataque a ela implicar um ataque a todo um conjunto de outros elementos. E a autoridade desta teoria resultará de tal invulnerabilidade. Assim, Latour nos informa que Watson e Crick, ao trazerem a público a teoria da dupla hélice, preocuparam-se com coisas que nada têm a ver com os méritos intrínsecos desta teoria. Eles se preocuparam, por exemplo, em avaliar a reputação de Linus Pauling e o nível dos estudantes de Cal Tech. $\underline{16}$ Eu me pergunto que relevância esse tipo de informação pode ter. Latour afirma que tais precauções foram cruciais na disputa pela prioridade na descoberta da estrutura molecular do DNA. Não duvido que isto seja verdade, mas esta verdade é uma nota de rodapé se comparada a outras verdades sobre as quais a metáfora da caixa-preta não tem nenhuma luz a jogar. Por exemplo, a de que a teoria da dupla hélice deu novo fôlego à (então quase centenária) teoria darwiniana de que há uma continuidade entre todas as espécies, ou a de que ela teve um enorme impacto na imunologia, posto que reabilitou as teorias imunológicas de molde selecionista, que haviam sido enterradas nos anos 10. Estou certo de que esse impacto nada deve às precauções de Watson e Crick em relação a Linus Pauling, nem a qualquer estratégia que Watson e Crick ou quem quer que seja possa ter tomado em relação a esta teoria.

Mas, retomando o eixo central da discussão, a metáfora da caixa-preta, se aplicada às teorias científicas, nos leva a perguntar como pessoas determinadas vêm a dar mais ou menos importância (ou conferir mais ou menos crédito) a teorias determinadas em circunstâncias determinadas. Em certas circunstâncias a teoria da dupla hélice pode mobilizar muita atenção e dinheiro, em outras pode não mobilizar 
nada; em certas circunstâncias esta teoria se presta a certos usos, em outras, a outros usos; em certas circunstâncias atacar esta teoria seria como atirar uma pedra em uma casa de marimbondos, em outras, tal ataque envolveria, se tanto, um debate acadêmico. Latour quer entender como tudo isto se dá. Sua resposta, em linhas gerais, seria a seguinte: tudo depende dos elementos aos quais esta teoria vem a ser encadeada. Se encadeada aos elementos "a", "b", "c" e "d", ela se presta aos usos "x" e "y", e atacá-la seria como cutucar uma caixa de marimbondos; se encadeada aos elementos "a", "b", "f" e "g", ela se presta ao uso "z" e atacá-la não teria nenhuma repercussão. Se por qualquer razão o uso "z" deixar de ser conveniente para um grupo determinado de pessoas, então estas pessoas não vão mais encadeá-la aos elementos "f" e "g", mas vão tentar encadeá-la a "h" e "i". E assim por diante.

Reconheço que tudo isto pode ser verdade mas, como já deixei claro, não vejo que interesse esta verdade pode ter, porque salta à vista um sério inconveniente em relação a tudo isto: nos marcos do raciocínio apresentado, o fato de estarmos lidando com nada menos do que a realização científica mais importante deste século torna-se um mero detalhe. Latour, evidentemente, poderia responder que a teoria da dupla hélice não é, em si, a realização científica mais importante deste século, e que o simples fato de as pessoas a considerarem assim é o resultado desta teoria ter sido encadeada a toda sorte de elementos (ou de ter sido tornada um segmento de uma rede bastante estável), de forma a tornar-se imprescindível para muitas atividades institucionalizadas. Provavelemente, isto também é verdade mas, mais uma vez, uma verdade irrelevante, porque torna a teoria da dupla hélice tão importante quanto qualquer outro item do conhecimento que se tenha tornado imprescindível para muitas atividades institucionalizadas. Do ponto de vista do conhecimento, o que importa saber a respeito da teoria da dupla hélice não é como ela veio a se tornar imprescindível para determinadas atividades ou instituições, mas sim que problemas esta teoria resolve, que problemas ela levanta, que teorias ela reforça ou reabilita, que teorias ela enfraquece ou derruba, quais são suas conseqüencias empíricas e em que circunstâncias experimentais ela se revelaria insustentável. Latour nada tem a dizer sobre nada disto e, pior do que isso, ele desvia nossa atenção dessas perguntas. Se se trata de dizer alguma coisa relevante sobre o conhecimento, penso que isto não é uma limitação menor.

Não obstante esta limitação, há uma circunstância na qual a metáfora da caixa-preta poderia revelar-se de enorme interesse. Para explicar esse ponto vou recorrer a mais uma analogia, a dos sistemas de videocassete. No início dos anos 80 havia dois sistemas alternativos de videocassete, os chamados VHS e BETAMAX. Hoje, como sabemos, o sistema BETAMAX não existe mais. Sabemos também que a extinção desse sistema nada tem a ver com a sua qualidade. Ao contrário, há quem diga que o sistema BETAMAX era melhor do que o VHS. Admito que a metáfora da caixa-preta pode nos ajudar a entender por que o sistema VHS prosperou e o BETAMAX se extinguiu. Ela nos convidaria a explicar esse ponto não em termos das qualidades intrínsecas de cada sistema, mas em termos dos usos aos quais cada um se prestou quando foram lançados no mercado, e este uso seria uma decorrência da maneira pela qual, naquela ocasião, cada sistema veio a ser encadeado a outros elementos. Posta a analogia, a metáfora da caixa-preta poderia ser de grande interesse se se pudesse mostrar que a trajetória das teorias científicas é análoga à trajetória de sistemas de videocassetes. Nesta perspectiva, tomar a teoria da dupla hélice como uma caixa-preta poderia ser de grande interesse se se pudesse mostrar que houve no passado alguma teoria alternativa que, embora fosse igualmente boa, se extinguiu em razão de não estar encadeada a elementos que garantissem sua força. Em outras palavras, a referida metáfora seria de enorme interesse se se pudesse mostrar que houve no passado alguma teoria que esteve para a teoria da dupla hélice como o sistema BETAMAX esteve um dia para o sistema VHS.

A bem da verdade, foi nessa direção que Latour se moveu em seu citado artigo "Give-me a laboratory and I will raise the world". Em última análise, o ponto central desse artigo é o de que a teoria da fermentação de Pasteur teve seu BETAMAX, a saber, a teoria da geração espontânea, defendida por um certo Pouchet. Como filho feio não tem 
pai, Latour certamente não se diria alinhado (como, de resto, ninguém de bom senso) à tese de que a vitória de Pasteur sobre Pouchet é da mesma natureza que a vitória do sistema VHS sobre o sistema BETAMAX. Entretanto, essa tese é o resultado inevitável (é o filho feio, sem pai) da aplicação da metáfora da caixa-preta ao conhecimento.

Ao lado de sua proposta de conceber teorias como "caixaspretas", Latour menciona e demonstra grande apreço por uma distinção entre o que ele chama de "ciência em construção" ("science in the making") e ciência "já feita" ("ready-made science"). Uma vez feita esta distinção, ele quer entender a ciência "já feita" a partir do exame de como a ciência "se faz". Daí sua atração por controvérsias (como também pela referida metáfora da caixa-preta). Um ponto curioso em relação aos estudos que se baseiam no exame de controvérsias é que eles nunca se empenham em examinar os desdobramentos posteriores da controvérsia examinada. Um livro intitulado Species and specificity. An interpretation of the history of immunology, de Pauline Mazumbar (1995), constitui uma excelente ilustração deste ponto. Mazumbar examina com detalhes a controvérsia havida no início deste século entre dois gigantes da imunologia, Paul Ehrlich e Karl Landsteiner. Ela mostra que esta controvérsia é um eco de outra controvérsia, havida uns 50 anos antes, entre dois expoentes da botânica, Cohn e von Nägeli. Ela mostra ainda que a controvérsia entre Ehrlich e Landsteiner ecoou em mais uma geração de imunologistas. Em resumo, ela rastreou uma controvérsia que se estendeu por mais de cem anos. Mas ela não discute o que interessa, a saber, a importância dessa controvérsia para o desenvolvimento da imunologia moderna.

Ela não se pergunta, por exemplo, em que a imunologia moderna teria sido diferente se a teoria das cadeias laterais de Ehrlich não tivesse sido tão duramente contestada por Landsteiner. Penso que a discussão de Mazumbar só teria interesse se ela pudesse oferecer uma boa resposta para essa pergunta, e Mazumbar sequer se fez essa pergunta.

Mas, cabe a pergunta, o que há de errado em examinar uma controvérsia sem se preocupar em examinar seus desdobramentos posteriores? Por que examinar os desdobramentos posteriores de uma controvérsia é mais importante do que examinar seus "bastidores" (à Mackenzie), ou rastrear seus antecedentes (à Mazumbar), ou indagar sobre as maneiras pelas quais elas são (ou não) resolvidas em situações particulares (à Latour)? Minha resposta é a seguinte: penso que controvérsias só são importantes na medida em que se aprende algo importante com elas. Examinar uma controvérsia sem dizer o que se aprendeu com ela é tornar essa controvérsia uma mera curiosidade. Desse ponto de vista, o que precisamos saber a respeito de uma controvérsia é o que se aprendeu com ela e que frutos este aprendizado gerou — e, lamentavelmente, nem Mackenzie, nem Mazumbar, nem Latour nada têm a dizer sobre isto.

Em contrapartida, Alfred Tauber, em uma série de artigos, ilustra exemplarmente bem como fazer bom uso de um exame de controvérsias (Tauber, 1990 e 1991; Tauber e Chernyak, 1989 e 1991; Chernyak e Tauber, 1988). De acordo com Tauber, Metchnikoff (que dividiu com Ehrlich o Prêmio Nobel de Medicina em 1908) é responsável pelo que há de mais importante na imunologia moderna, a saber, a idéia de que a ação do organismo é fundamental para a imunidade. Este legado, diz Tauber, pode ser mais claramente entendido se se retomar a controvérsia entre Metchnikoff e Haeckel a respeito das relações entre ontogenia e filogenia, isto é, se não se perder de vista o fato de que Metchnikoff superou a teoria de Haeckel de que a ontogenia recapitula a filogenia com uma apreciação mais complexa do desenvolvimento ontogênico. Um desdobramento importantíssimo desta controvérsia foi a rejeição da tese de que há um padrão único de gastrulação, e Tauber examina as implicações desta rejeição para o desenvolvimento da imunologia moderna. $\frac{17}{} \mathrm{O}$ trabalho de Tauber constitui, então, um ótimo exemplo de como examinar controvérsias sem incorrer na ironia paroquial da sociologia do conhecimento de matriz wittgensteiniana. Ao manter-se devidamente afastado desta ironia, Tauber nos presenteou com uma discussão que de fato interessa: o que Metchnikoff aprendeu a partir de sua polêmica com Haeckel e qual o impacto desse aprendizado sobre o estado atual do conhecimento em imunologia. 
O mesmo, infelizmente, não pode ser dito de Mazumbar. Ela pendeu muito mais para o lado de Latour do que para o lado de Tauber e em momento algum se perguntou o que Ehrlich aprendeu a partir de sua polêmica com Landsteiner, ou o que Wiener (um sucessor de Landsteiner) aprendeu a partir de sua polêmica com Fisher (um sucessor de Ehrlich), e que importância tais polêmicas tiveram para o desenvolvimento posterior da imunologia. Embora não tenha citado Latour, e ainda que não o conhecesse ao escrever o referido Species and specificity, ela de certa forma seguiu seu conselho e procurou chegar à ciência "já feita" através do exame da ciência "em construção". O resultado, receio dizer, não recomenda tal procedimento. Apesar de ser um livro cuja riqueza historiográfica é provavelmente sem paralelo, não sou capaz de dizer se ele responde alguma pergunta. Pior do que isto, não sei dizer se ele levanta alguma questão. Em contraste, um artigo de D. Talmage (1995) e outro de G. Nossal (1995), ambos comparativamente pobres de um ponto de vista historiográfico, levantam questões que me parecem muito importantes, tais como, por exemplo, por que a teoria das cadeias laterais de Ehrlich foi enterrada em torno de 1910 e reabilitada 40 anos depois, e que continuidade existe entre essa teoria e a teoria dos rearranjos gênicos, formulada 80 anos depois.

Se tais perguntas puderam ser formuladas é porque Talmage e Nossal (sem falar em Tauber) não se preocuparam com a "ciência em construção" e sim com a "ciência já feita". Ao invés de ironizarem a teoria das cadeias laterais examinando o processo por meio do qual Ehrlich a formulou, e as estratégias que ele adotou para obter o assentimento dos seus pares, eles tomaram distância do processo de formação desta teoria e se perguntaram, em primeiro lugar, em que medida Ehrlich estava certo (pergunta que Mazumbar jamais se fez), em segundo, por que os anos 10 não estavam preparados para Ehrlich, em terceiro, que correções a teoria das cadeias laterais estava demandando e, finalmente, de que outras teorias, formuladas em anos posteriores, e em outros campos do conhecimento, a teoria de Ehrlich pôde se beneficiar (a teoria da dupla hélice, diga-se de passagem, foi uma destas teorias).

Disso decorre que vamos bem mais longe examinado a ciência como um produto do que examinando a ciência como um processo. $\frac{18}{\mathrm{Em}}$ forte oposição a Latour, penso que o exame da ciência "já feita" pode nos dizer muito sobre a ciência "em construção", mas a recíproca não é verdadeira. Penso que pretender dizer alguma coisa de relevante sobre a ciência examinando os processos por meio dos quais ela "se faz" é um grave equívoco. Este equívoco torna-se evidente se examinarmos mais uma metáfora de Latour. Em seu citado "The impact of science studies on political philosophy" Latour vangloria-se por examinar a ciência em sua "linha de montagem", ao invés de examiná-la "fora de sua linha de montagem". Esta metáfora mostra bem o quanto escapa a Latour o que há de realmente importante em relação à ciência. Só faz sentido examinar um automóvel em sua linha de montagem se já soubermos de antemão como será este automóvel fora de sua linha de montagem. Como é perfeitamente possível ter esse conhecimento, então faz todo sentido examinar um automóvel em sua linha de montagem. Mas, se de uma mesma linha de montagem pudesse sair tanto um ótimo quanto um péssimo automóvel, então o exame do que se passa nessa linha de montagem não teria qualquer interesse.

E é exatamente isto o que ocorre em relação à ciência. No caso da ciência, não é possível saber de antemão que produto resultará de uma determinada atividade. De uma mesma "linha de montagem" pode sair tanto um modelo da dupla hélice quanto uma teoria que não resiste ao primeiro sopro. Da "linha de montagem" de Pasteur, por exemplo, saiu tanto a teoria da fermentação, que é ainda válida, quanto a teoria da depleção (à qual, pelo que sei, Latour jamais fez referência), cuja vida foi muitíssimo breve. Daí que examinar a ciência "em sua linha de montagem" é uma perda de tempo. A Latour parece escapar o fato de que as teorias científicas não são um produto da atividade humana no mesmo sentido em que um automóvel é um produto da atividade humana. Se fosse possível existir uma linha de montagem cujo produto final não se pudesse conhecer a priori, então a metáfora da linha 
de montagem seria adequada para a ciência. Mas, como a hipótese da existência de tal linha de montagem é um absurdo, então a proposta de examinar a ciência "em sua linha de montagem" não é nada que mereça celebração.

Há, entretanto, uma razão ainda mais forte para rejeitar a idéia de que o exame da ciência "em construção" é relevante. Em uma linha de montagem de verdade, todo (ou pelo menos quase todo) produto que vem a ser montado é retido. Seria um absurdo montar cem carros para aproveitar um e eliminar os demais. Mas, no caso da ciência, é exatamente isto o que ocorre. "Monta-se" muito e aproveita-se pouco. Daí que querer dizer alguma coisa relevante sobre o conhecimento concentrando-se na sua "construção social" envolve desconhecer que apenas uma pequena proporção do que se constrói permance de pé e que, portanto, muito mais importante do que mostrar o caráter "socialmente construído" do conhecimento é explicar o que mantém esta referida pequena proporção de pé.

Quero, para concluir, mencionar que a obra de Latour não poderia ser considerada um exemplo de sociologia não paroquial porque, a exemplo dos construtivistas, Latour nunca tomou a devida distância dos processos sobre os quais se debruçou. $\mathrm{O}$ fato de ter se mantido a um palmo das controvérsias e das estratégias adotadas pelos cientistas para construir e usar "caixas-pretas" levou Latour (e, na verdade, a maioria dos sociólogos e filósofos de inspiração wittgensteiniana) a pensar que o que há de importante em relação às teorias científicas é o fato de haver algumas pessoas convencidas de sua validade. Penso que é enorme o mérito de Popper por ter derrubado esta versão particularmente pobre da visão paroquial da ciência ao mostrar que o assentimento a uma teoria é um fato de importância secundária. O que há de verdadeiramente importante para saber a respeito do conhecimento está fora do alcance de qualquer sociologia paroquial do conhecimento. Refiro-me à capacidade que as teorias exibem de encerrar problemas e implicações que acabam por se impor à comunidade científica, de provocar críticas e tirar proveito delas, de se beneficiar do contato com outras teorias, de destruir ou reabilitar teorias anteriores, de ressurgir das cinzas com a ajuda de teorias posteriores e, sobretudo, de resistir a qualquer forma de paroquialismo.

\section{NOTAS}

1 Esta distinção é inspirada em Woolgar (1983).

2 Conforme argumentarei posteriormente, controvérsias são importantes apenas na medida em que se aprende algo com elas. Isto significa que muito mais importante do que reconstruir a história de uma controvérsia, ou examinar seus "bastidores", ou as maneiras pelas quais ela se resolve em uma situação particular, é perguntar o que se aprendeu a partir dela, e isto Latour jamais fez. Em outras palavras, muito mais importante do que examinar uma controvérsia é indagar sobre seus desdobramentos, e isto não pode ser feito nos marcos do paroquialismo da sociologia do conhecimento de matriz wittgensteiniana. Eu discuto este ponto em detalhes em Springer de Freitas (1998).

$\underline{3}$ Eu desenvolvo este ponto em meu citado artigo de 1993, p. 231.

4 Veja-se Bloor (1991[1976]), Barnes (1977), Latour e Woolgar (1979), Knorr-Cetina (1981), Collins (1985) e Lynch (1985).

5 Salvo engano, esta solução foi originalmente proposta por Donald Campbell, e ficou conhecida como o "realismo hipotético". Veja-se Campbell (1960).

6 Este defunto é também o sparring do renomado filósofo pragmatista Richard Rorty (veja-se, a respeito, Peter Munz, 1987). Rorty tem razão quando rejeita a tese de que "há procedimentos de justificação de crença que são naturais e não meramente locais" (Rorty, 1993, p. 111). Entretanto, se ele dialogasse com Popper, ao invés de se contentar em golpear um defunto, ele veria que a rejeição de tal tese não precisa necessariamente conduzir ao paroquialismo pragmatista que ele endossa. A rejeição (bastante razoável) da tese de que há procedimentos naturais de justificação de 
crença pode também conduzir à tese não paroquial de que o conhecimento nada tem a ver com crença nem, muito menos, com a justificação de uma crença, mas sim com a possibilidade de criticar afirmações. Não vamos muito longe nos perguntando como alguém pode justificar sua crença na tese de que o homem descende do macaco. Um quadro mais promissor se vislumbra se nos perguntarmos como esta mesma tese pode ser criticada, com que outras teses esta tese pode ser comparada etc.

7 Veja-se, especialmente, David Bloor (1991[1976], p. 16).

$\underline{8}$ Cabe nesse ponto ressaltar que a metodologia utilizada pelos legistas para concluir que uma morte resultou de suicídio (e não, por exemplo, de um acidente) pode ser criticada de forma não irônica. Este é o procedimento da Sociologia clássica. Assim, em O suicídio Durkheim critica os métodos utilizados na obtenção de dados estatísticos sobre causas de suicídio visando alertar o leitor quanto à precariedade desses dados. Isto não envolve ironizar estes dados, isto é, não envolve convidar o leitor a ver nesses dados legistas falando de si mesmos ao decidirem sobre a causa de um suicídio.

9 Devo este ponto inteiramente a Steve Woolgar (1983), embora lamente que ele não tenha sequer considerado a possibilidade de buscar em Popper uma alternativa tanto para a "posição reflexiva" quanto para o paroquialismo inerente à posição construtivista.

10 Em claro contraste com o que ocorre, por exemplo, em relação à famosa tese de Clifford Geertz de que a briga de galos em Bali envolve uma "educação sentimental", isto é, o uso de emoções (tais como a excitação do risco, ou o desespero da derrota, ou o prazer da vitória) para fins cognitivos. Eu discuto o caráter paroquial desta tese em outro trabalho (Springer de Freitas e Batitucci, 1997). Procuro mostrar que não há como criticar esta tese à luz de outras teses ou de qualquer informação que não seja as fornecidas pelo próprio Geertz. Por outro lado, esta tese depende inteiramente da boa vontade do leitor em concordar que uma peça de Shakespeare é uma analogia apropriada para uma briga de galos em Bali.
11 O leitor pode se perguntar como pude apresentar Durkheim como uma espécie de pai fundador da sociologia paroquial do conhecimento e, alguns parágrafos adiante, mencioná-lo como um modelo de sociologia não paroquial. A resposta, muito simples, é a de que a obra de Durkheim é imensa e, felizmente, só uma pequena parte desta obra foi contaminada pelo paroquialismo durkheimiano.

12 Devo deixar claro que, muito provavelmente, Schwartzman não endossaria o argumento que estou desenvolvendo aqui. Ele não partilha de minhas objeções a Latour, como se vê em Schwartzman (1994).

13 Esta lista de elementos foi inventada por mim e não por Shapin, mas, suponho, ilustra bem o raciocínio de Shapin (e de Latour).

14 Em conexão com esse ponto, Shapin chega a afirmar, na página 308 de seu citado artigo, que "quando todos os elementos em uma rede agem em conjunto para proteger um item do conhecimento, este item torna-se forte e nós o chamamos de científico". Não sei quão fiel ao pensamento de Latour esta afirmação de Shapin é. Seja como for, na minha opinião esta afirmação é um claro disparate.

15 Latour oferece este exemplo em seu livro Science in action (1987), o qual, diga-se de passagem, mereceu um artigo intitulado "Surely you are joking, Monsieur Latour" (Amsterdamska, 1990).

16 Latour fornece esta informação em seu citado Science in action, p. 6.

17 Eu desenvolvo este ponto em meu citado artigo "Por que estudar controvérsias científicas?" (Springer de Freitas, 1998).

18 A propósito, Science as a process (1988) é o título de um livro muito aclamado nos últimos anos. $\mathrm{O}$ autor, $\mathrm{O}$ kuhniano David Hull, inicia este livro nos seguintes termos: "This book concerns science. How do scientists choose between alternative views of the world?". Contrariando Hull, penso que se o "concern" é mesmo a ciência, então 
indagar como os cientistas escolhem entre visões alternativas do mundo não é um bom começo. Um bom começo seria indagar como estas visões podem se beneficiar das críticas que são dirigidas às teorias que elas abrigam. Assim, entender, por exemplo, como os cientistas vêm a se alinhar ao darwinismo é muitíssimo menos importante do que entender como o darwinismo pode prosperar em decorrência das críticas formuladas a determinadas teorias desenvolvidas em seu interior (eu discuto esse ponto em Springer de Freitas, 1997).

\section{BIBLIOGRAFIA}

AMSTERDAMSKA, O. (1990), "Surely you are joking, monsieur Latour". Science, Technology \& Human V alues, 15(4): 495-504.

ATKINSON, J.M. (1978), Discovering suicide: studies in the social organization of sudden death. Londres, MacMillan.

BARNES, B. (1977), Interests and the growth of knowledge. Londres, Routledge.

BARTLEY, W.W., III. (1987), "Philosophy of biology versus philosopy of physics", in G. Radnitzky e W.W. Bartley, III (orgs.), Evolutionary epistemology, rationality, and the sociology of knowledge, La Salle, Open Court, pp. 7-45.

BLOOR, D. (1991[1976]), Knowledge and social imagery. Londres, Routledge.

CAMPBELL, D.T. (1960), "Blind variation and selective retention in creative thought as in other knowledge processes". The Psychological Review, 67: 380-400.

CHERNYAK, L. e TAUBER, A. (1988), "History of immunology. The birth of immunology: Metchnikoff, the embryologist". Cellular Immunology, 117: 218-233.

CICOUREL, A.V. (1968), The social organization of juvenile justice. Nova York/ Londres, Wiley.
COLLINS, H. (1985), Changing order: replication and induction in scientific practice. Londres, Sage.

DOUGLAS, J. (1967), The social meaning of suicide. Princeton, Princeton University Press.

HULL, D. (1988), Science as a process. Chicago, The University of Chicago Press.

KIERKEGAARD, S. (1965), The concept of irony. Bloomington, Indiana University Press.

KNORR-CETINA, K. (1981), The manufacture of knowledge: toward a constructivist and contextual theory of science. Oxford, Pergamon.

LATOUR, B. (1983), "Give me a laboratory and I will raise the world", in K. Knorr-Cetina e M. Mulkay (orgs.), Science observed, Londres/Beverly Hills, Sage, pp. 141-170.

. (1987), Science in action. Cambridge, Harvard

University Press. . (1990), "Post-modern? No, simply amodern! Steps towards an anthropology of science". Studies in History and Philosophy of Science, 21(1): 145-171.

(1991), "The impact of science studies on political philosophy". Science, Technology \& Human Values, 16(1): 3-19.

LATOUR, B. e WOOLGAR, S. (1979), Laboratory life: the social construction of scientific facts. London, Sage.

LYNCH, M. (1985), Art and artifact in laboratory science: a study of shop work and shop talk in a research laboratory. Londres, Routledge and Kegan Paul.

MACKENZIE, D. (1978), "Statistical theory and social interests: a case study". Social Studies of Science, 8: 35-83.

MAZUMBAR, P. (1995), Species and specificity. An interpretation of the history of immunology. Cambridge, Cambridge University Press. 
MUNZ, P. (1987), "Philosophy and the mirror of Rorty", in G. Radnitzky e W.W. Bartley, III (orgs.), Evolutionary epistemology, rationality, and the sociology of knowledge, La Salle, Open Court, pp. 345-398.

NOSSAL, G. (1995), "One cell — one antibody", in R. Allagher, J. Gilder, G.J.V. Nossal e G. Salvatore (orgs.),Immunology: the making of a modern science, Londres, Harcourt Brace \& Company, pp. 39-47.

POPPER, K. (1992 [1972]), Objective knowledge. 7a. ed., Oxford, Clarendon Press.

RORTY, R. (1993), "Solidariedade ou objetividade?". Novos Estudos, 36: 109-121.

SCHWARTZMAN, S. (1994), "Os dinossauros de Roraima (ou a sociologia da ciência e da técnica de Bruno Latour)". Novos Estudos, 39: 172-179. . (1997), A redescoberta da cultura. São Paulo, EDUSP.

SHAPIN, S. (1995), "Here and everywhere: sociology of scientific knowledge". Annual Review of Sociology, 21: 289321.

SPRINGER DE FREITAS, R. (1993), "Construtivismo e ironia sociológica". Novos Estudos, São Paulo, Cebrap, 36, julho: 223-233.

(1997), "Back to Darwin and Popper: criticism, migration of piecemeal conceptual schemes, and the growth of knowledge". Philosophy of the Social Sciences, 27(2): 157-179.

(1998), "Por que estudar controvérsias científicas?". Episteme, Filosofia e História das Ciências em Revista, 3(6): 208-221.

SPRINGER DE FREITAS, R. e BATITUCCI, E. (1997), "A falácia da interpretação da cultura como texto". Lua Nova, 40/41: 267-288.
TALMAGE, D. (1995), "Origins of the cell selection theories of antibody formation",in R. Allagher, J. Gilder, G.J.V. Nossal e G. Salvatore (orgs.), Immunology: the making of a modern science, Londres, Harcourt Brace \& Company, pp. 26-38.

TAUBER, A. (1990), "Metchnikoff, the modern immunologist". Journal of Lenkocyte Biology, 47: 561-567. . (1991), "The immunological self: a centenary perspective". Perspectives in Biology and Medicine, 5(1): 7486.

TAUBER, A. e CHERNYAK, L. (1989), "History of immunology. The birth of immunology: Metchnikoff and his critics".Cellular Immunology, 121: 447-473.

- (1991), Metchnikoff and the origins of immunology: from metaphor to theory. Oxford, Oxford University Press.

WOOLGAR, S. (1983), "Irony in the social study of science", inK. Knorr-Cetina e M. Mulkay (orgs.), Science observed, Londres, Sage, pp. 239-266.

* Registro meu reconhecimento ao professor Simon Schwartzman por sua valiosa crítica a uma versão anterior deste trabalho. 